\title{
PERAN STRUKTUR MODAL DALAM MEMEDIASI PENGARUH PERTUMBUHAN PERUSAHAAN TERHADAP NILAI PERUSAHAAN PADA PERUSAHAAN PROPERTI DI BEI
}

\author{
Kadek Ayu Citra Pradnya Paramita Parta ${ }^{1}$ \\ Ida Bagus Panji Sedana ${ }^{2}$
}

\author{
${ }^{1,2}$ Fakultas Ekonomi dan Bisnis Universitas Udayana, Bali, Indonesia \\ e-mail: paramitaparta@gmail.com
}

\begin{abstract}
ABSTRAK
Nilai perusahaan adalah nilai dalam jumlah uang yang dimana pembeli mampu dan bersedia membayar ketika perusahaan dijual. Nilai perusahaan dianggap penting karena nilai tersebut mencerminkan kinerja dari perusahaan yang mampu mempengaruhi persepsi investor terhadap perusahaan. Tujuan penelitian ini adalah untuk mengetahui pengaruh peran struktur modal dalam memediasi pengaruh pertumbuhan perusahaan terhadap nilai perusahaan pada perusahaan Properti di Bursa Efek Indonesia. Teknik pengambilan sampel yang digunakan adalah purposive sampling, dan didapatkan 32 sampel perusahaan Properti dan Real Estate periode 2013-2016. Metode pengumpulan data adalah observasi non partisipan. Data yang digunakan diperoleh melalui situs www.idx.co.id. Teknik analisis adalah analisis path dan uji sobel. Hasil analisis menunjukkan pertumbuhan perusahaan berpengaruh positif signifikan terhadap struktur modal, pertumbuhan perusahaan berpengaruh positif dan signifikan terhadap nilai perusahaan, struktur modal berpengaruh positif dan signifikan terhadap nilai perusahaan dan struktur modal mampu memediasi pengaruh pertumbuhan perusahaan terhadap nilai perusahaan.
\end{abstract}

Kata kunci : nilai perusahaan, struktur modal, pertumbuhan perusahaan.

\begin{abstract}
The value of the firm is the value in the amount of money that the buyer is able and willing to pay when the company is sold. The value of the company is considered important because the value reflects the performance of the company that is able to influence investors' perceptions of the company. The purpose of this study is to determine the effect of the role of capital structure in mediating the influence of corporate growth on the value of the company in the company Property on the Indonesia Stock Exchange. The sampling technique used was purposive sampling, and obtained 32 samples of Property and Real Estate company period 2013-2016. Data collection method is non participant observation. The data used is obtained through the website www.idx.co.id. Analysis technique is path analysis. The result of analysis shows that company growth has a significant positive effect on capital structure, firm growth has positive and significant effect to firm value, capital structure has positive and significant influence to firm value and capital structure able to mediate the influence of company growth on company value.
\end{abstract}

Keywords : firm value, capital structure, growth firm. 


\section{PENDAHULUAN}

Pertumbuhan ekonomi Indonesia saat ini semakin meningkat, sehingga menyebabkan terjadinya peningkatan persaingan bisnis oleh berbagai perusahaan. Persaingan bisnis tersebut menyebabkan berbagai perusahaan berusaha untuk melakukan berbagai upaya untuk dapat meningkatkan nilai perusahaannya. Salah satu faktor mendasar yang dapat meningkatkan nilai perusahaan adalah dengan meningkatkan kinerja dari berbagai aktivitas yang dilakukan perusahaan. Nilai perusahaan adalah nilai dalam jumlah uang yang dimana pembeli mampu dan bersedia membayar ketika perusahaan dijual (Husnan, 2014:17).

Nilai perusahaan dianggap penting karena nilai tersebut mencerminkan kinerja dari perusahaan yang mampu mempengaruhi persepsi investor terhadap perusahaan. Semakin tinggi nilai perusahaaan menggambarkan semakin sejahtera pemilik perusahaan (Kusumajaya, 2011:20). Kemakmuran pemegang saham dapat dicerminkan dari nilai perusahaan, semakin tinggi nilai perusahaan akan berdampak pada semakin meningkat pula kemakmuran pemegang sahamnya begitupula sebaliknya. Banyak faktor yang mempengaruhi nilai perusahaan, dua diantaranya adalah pertumbuhan perusahaan dan struktur modal. Menurut Sujoko dan Soebiantoro (2007), faktor penentu nilai perusahaan terdiri dari faktor ekstern perusahaan (tingkat suku bunga, keadaan pasar modal, pertumbuhan pasar) dan faktor intern perusahaan (pembayaran deviden, ukuran perusahaan dan profitabilitas).

Nilai perusahaan yang dicerminkan dari harga saham tahun $t_{+1}$ didefinisikan sebagai persepsi investor mengenai kemampuan perusahaan dalam pengelolaan 
sumber daya perusahaan pada tahun $\mathrm{t}$ (tahun berjalan) (Sujoko dan Soebiantoro, 2007). Untuk dapat meningkatkan nilai perusahaan manajemen akan menerapkan tata kelola perusahaan yang baik serta mempublikasikan informasi yang dapat meningkatkan nilai perusahaannya. Pernyataan tersebut sejalan dengan teori sinyal (signaling theory) yang menyebutkan bahwa isyarat atau signal sebagai suatu tindakan yang dilakukan oleh manajemen perusahaan untuk memberikan arahan kepada investor mengenai pandangan manajemen terhadap prospek perusahaan. Jika manajemen mengungkapkan informasi positif untuk masa depan perusahaan dan membutuhkan modal tambahan, maka pendanaan dengan menggunakan utang cenderung digunakan oleh manajemen perusahaan. Perusahaan yang memiliki potensi baik dimasa depan cenderung memilih pendanaan menggunakan utang, namun perusahaan yang memiliki potensi kurang baik dimasa depan cenderung memilih pendanaan menggunakan ekuitas luar.

Nilai perusahaan mengalami peningkatan dan penurunan setiap tahunnya dari tahun 2013-2016 yang ditunjukan dalam grafik dibawah ini, dimana ada beberapa perusahaan memiliki nilai $P B V$ menurun yang mengindikasikan menurunnya kualitas dan kinerja fundamental perusahaan. Perusahaan yang memiliki nilai $P B V$ menurun tentunya juga akan memperlambat pertumbuhan perusahaan sehingga perusahaan perlu meningkatkan pertumbuhan perusahaan, dikarenakan stabilnya pertumbuhan perusahaan dapat melirik investor untuk menanam modal di perusahaan dan akan berpengaruh terhadap peningkatan nilai perusahaan. Struktur modal yang optimal dalam perusahaan sangat berperan penting untuk keberlangsungan operasional perusahaan kedepannya. 


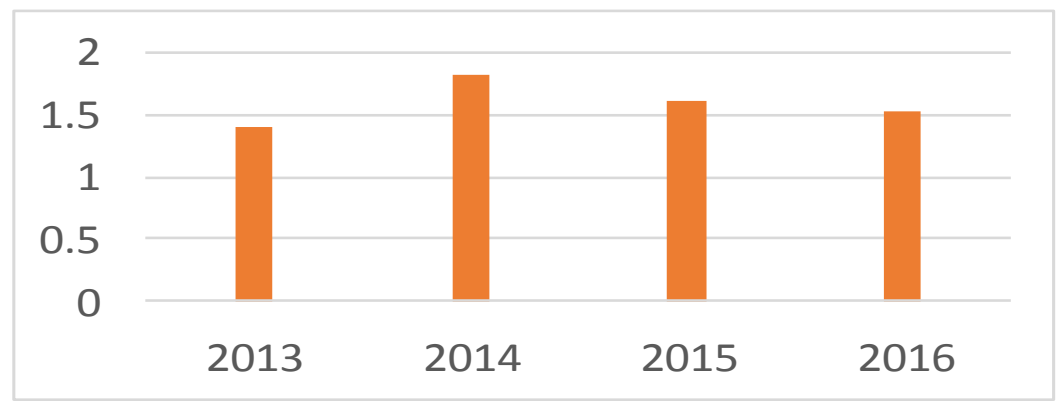

Gambar 1. Grafik nilai rata - rata $P B V$ tahun 2013 - 2016

Sumber: Ringkasan Laporan Keuangan Perusahaan BEI

Dalam memaksimalkan nilai perusahaan tentunya perusahaan memperhatikan keputusan mengenai struktur modal. Struktur modal yang optimal adalah struktur modal yang mengoptimalkan keseimbangan antara risiko dan pengembalian sehingga dapat memaksimumkan harga saham. Struktur modal yang optimum dapat dicapai dengan meminimumkan penggunaan biaya modal rata - rata tertimbang suatu perusahaan, yang tercakup didalamnya adalah biaya modal dan biaya hutang jangka panjang (Kuncoro dkk, 2016). Modal dapat berasal dari modal sendiri atau dari dana pinjaman (utang). Oleh karena itu sangat penting untuk mengetahui cara menentukan struktur modal yang optimal, terlebih lagi untuk perusahaan yang go public di pasar modal. Struktur modal struktur modal adalah proporsi dalam menentukan pemenuhan kebutuhan belanja perusahaan, di mana dana yang diperoleh menggunakan kombinasi atau panduan sumber yang berasal dari dana jangkap panjang yang berasal dari dalam dan luar perusahaan. (Rodoni dan Ali, 2014). Menurut Riyanto (2015:209) pendanaan perusahaan dapat diperoleh dari sumber internal (internal financing) dan sumber eksternal (external financing). Pendanaan perusahaan dengan sumber internal adalah dana yang dihasilkan atau dibentuk sendiri dari dalam perusahaan yang 
dapat berupa penyusutan dan laba ditahan. Pendanaan perusahaan dengan sumber eksternal adalah dana yang dihasilkan dari luar perusahaan yakni dari para kreditur dan pemilik, pengambil bagian atau peserta dalam perusahaan. Faktor yang berpotensi mempengaruhi struktur modal diantaranya tingkat pertumbuhan perusahaan.

Pertumbuhan perusahaan dapat diproksikan dengan perbandingan perubahan pada total aset perusahaan saat ini terhadap perubahan di masa lalu. Perusahaan dengan pertumbuhan tinggi dan volatilitas arus kas yang tinggi memiliki insentif untuk mengurangi hutang dalam struktur modal perusahaan selama periode waktu tertentu (Fauziah dan Iskandar, 2015). Pertumbuhan perusahaan menunjukkan daya tahan perusahaan dalam kondisi kompetitif. Pertumbuhan perusahaan dapat diukur dengan pertumbuhan asset. Pihak internal maupun eksternal perusahaan sangat mengharapkan adanya pertumbuhan perusahaan, karena baiknya pertumbuhan perusahaan akan berdampak baik pula terhadap perkembangan perusahaan.

Teori trade-off menjelaskan bahwa apabila penambahan utang dilakukan dibawah batas atas struktur modal optimal perusahaan maka utang tersebut akan meningkatkan nilai perusahaan. Sebaliknya, apabila penambahan utang yang dilakukan melebihi batas atas struktur modal optimal perusahaan, maka utang tersebut dapat menurunkan nilai perusahaan. Nilai perusahaan mencerminkan kemakmuran dari pemegang saham dan juga kinerja perusahaan. Dari teori tradeoff tersebut dapat dikatakan jika pertumbuhan perusahaan meningkat yang 
disebabkan oleh optimalnya posisi struktur modal maka secara langsung akan meningkatkan nilai perusahaan.

Perbedaan hasil penelitian (research gap) mengenai pengaruh variabel yang dijelaskan sebelumnya terhadap nilai perusahaan masih diperoleh pada beberapa hasil penelitian sebelumnya, maka penelitian ini dilakukan untuk memperjelas pengaruh faktor - faktor yang disebutkan sebelumnya terhadap nilai perusahaan pada sektor properti di Bursa Efek Indonesia periode tahun 2010-2014. Penelitian ini menguji tiga variabel penelitian ini yaitu struktur modal pertumbuhan perusahaan dan nilai perusahaan. Adapun tujuan dari penelitisn ini adalah untuk mengetahui signifikansi pengaruh pertumbuhan perusahaan terhadap struktur modal dan nilai perusahaan, dan untuk mengetahui signifikansi pengaruh struktur modal terhadap nilai perusahaan serta untuk mengetahui peran struktur modal dalam memediasi pengaruh pertumbuhan perusahaan terhadap nilai perusahaan.

Berdasarkan tujuan penelitian yang telah diuraikan, adapun kegunaan dari penelitian ini ada dua yaitu kegunaan praktis dari hasil penelitian ini diharapkan dapat digunakan sebagai bahan masukan di dalam manajemen keuangan khususnya berkaitan dengan pertumbuhan perusahaan, nilai perusahaan dan struktur modal. Kegunaan teoritis dari penelitian ini diharapkan dapat digunakan untuk menambah ilmu pengetahuan berupa penambahan bukti empiris tentang manajemen keuangan khususnya pertumbuhan perusahaan, nilai perusahaan dan struktur modal.

Menurut Pakpahan (2010) pertumbuhan adalah kemampuan perusahaan dalam mempertahankan kedudukannya saat terjadinya perkembangan ekonomi 
Kadek Ayu Citra Pradnya Paramita Parta, Peran Struktur Modal Dalam...

dan perkembangan industri yang dijalankan perusahaan. Pertumbuhan perusahaan dapat diproksikan dengan perbandingan perubahan pada total aset perusahaan saat ini terhadap perubahan di masa lalu. Pertumbuhan perusahaan memerlukan modal di luar cadangan internal untuk membiayai investasi mereka maka dari itu struktur permodalan sebuah perusahaan sangat penting karena berkaitan dengan kemampuan perusahaan untuk memenuhi kebutuhan para pemangku kepentingan (Velnampy dan Niresh, 2012), maka dari itu dengan meningkatnya pertumbuhan perusahaan akan menarik perhatian investor dan akan semakin banyak modal yang diperoleh perusahaan. Menurut teori trade off, apabila peluang pertumbuhan perusahaan semakin tinggi maka akan memiliki pendapatan yang lebih tinggi juga, sehingga perusahaan akan menerbitkan lebih banyak hutang untuk mempertahankan rasio hutang maka perusahaan cenderung memiliki struktur modal yang lebih tinggi (Chen dan Chen, 2011). Hasil penelitian yang dilakukan oleh Holong (2011) yang menemukan pertumbuhan positif dan signifikan mempengaruhi struktur modal.

$\mathrm{H}_{1}$ : Pertumbuhan perusahaan berpengaruh positif dan signifikan terhadap struktur modal.

Pertumbuhan perusahaan menunjukkan daya tahan perusahaan dalam kondisi kompetitif. Perusahaan yang besar lebih diminati daripada perusahaan kecil sehingga pertumbuhan perusahaan sangat mempengaruhi nilai perusahaan. Perusahaan dengan pertumbuhan total aktiva yang tinggi dapat meningkatkan nilai perusahaan. Hal ini menggambarkan kemampuan perusahaan memperoleh laba untuk menambah jumlah aktiva yang dimiliki semakin meningkat sehingga akan 
lebih diminati oleh investor. Dewi et al. (2014) telah melakukan penelitian dan menemukan bahwa terdapat pengaruh yang positif antara pertumbuhan perusahaan terhadap terhadap nilai perusahaan, temuan tersebut didukung oleh penelitian Sari dan Abundanti (2014) yang menemukan bahwa terdapat pengaruh yang positif dan signifikan antara pertumbuhan perusahaan terhadap nilai perusahaan.

$\mathrm{H}_{2}$ : Pertumbuhan perusahaan berpengaruh positif dan signifikan terhadap nilai perusahaan.

Teori trade-off menjelaskan bahwa apabila penambahan utang dilakukan dibawah batas atas struktur modal optimal perusahaan maka utang tersebut akan meningkatkan nilai perusahaan. Sebaliknya, apabila penambahan utang yang dilakukan melebihi batas atas struktur modal optimal perusahaan, maka utang tersebut dapat menurunkan nilai perusahaan. Maka dapat disimpulkan bahwa berdasarkan teori trade-off adanya hubungan yang positif antara struktur modal terhadap nilai perusahaan dengan mengasumsikan titik target struktur modal optimal belum tercapai (Dewi dan Wirajaya, 2013). Nilai perusahaan dianggap penting karena nilai tersebut mencerminkan kinerja dari perusahaan yang mampu mempengaruhi persepsi investor terhadap perusahaan, jika perusahaan mampu memenuhi kebutuhan para pemangku kepetingan maka nilai perusahaan akan meningkat.

Keputusan struktur modal perusahaan diuji dampaknya terhadap nilai perusahaan selanjutnya bahwa jika keputusan struktur modal dapat mempengaruhi nilai perusahaan, maka perusahaan ingin struktur modal yang memaksimalkan 
nilai mereka. Hasil penelitian Dewi et al. (2014) menemukan bahwa terdapat pengaruh yang positif signifikan antara struktur modal terhadap nilai perusahaan. Hamidy et al. (2015) telah melakukan penelitian dan menemukan bahwa terdapat pengaruh yang positif signifikan antara struktur modal terhadap nilai perusahaan. Temuan tersebut juga didukung oleh penelitian Rehman (2016) yang menemukan bahwa adanya hubungan yang positif antara struktur modal dan nilai perusahaan. $\mathrm{H}_{3}$ : Struktur modal berpengaruh positif dan signifikan terhadap nilai perusahaan. Pertumbuhan perusahaan dapat diproksikan dengan perbandingan perubahan pada total aset perusahaan saat ini terhadap perubahan di masa lalu, perusahaan sangat mengharapkan adanya pertumbuhan perusahaan karena baiknya pertumbuhan perusahaan akan berdampak baik pula terhadap perkembangan perusahaan. Cepatnya pertumbuhan perusahaan akan memerlukan pendanaan berupa modal karena struktur modal sangat berperan penting didalam pertumbuhan perusahaan. Modal didalam perusahaan sangat berperan penting dikarenakan jika perusahaan menggunakan modal sebaik-baiknya maka akan meningkatkan nilai dari perusahaan tersebut. Teori trade-off menjelaskan bahwa apabila penambahan utang dilakukan dibawah batas atas struktur modal optimal perusahaan maka utang tersebut akan meningkatkan nilai perusahaan. Sebaliknya, apabila penambahan utang yang dilakukan melebihi batas atas struktur modal optimal perusahaan, maka utang tersebut dapat menurunkan nilai perusahaan. Dari teori trade-off tersebut dapat dikatakan jika pertumbuhan perusahaan meningkat yang disebabkan oleh optimalnya posisi struktur modal maka secara langsung juga akan meningkatkan nilai perusahaan. 
$\mathrm{H}_{4}$ : Struktur modal mampu memediasi pengaruh pertumbuhan perusahaan terhadap nilai perusahaan.

Berdasarkan kajian teori dan hipotesis penelitian dapat disajikan kerangka konseptual seperti gambar berikut.

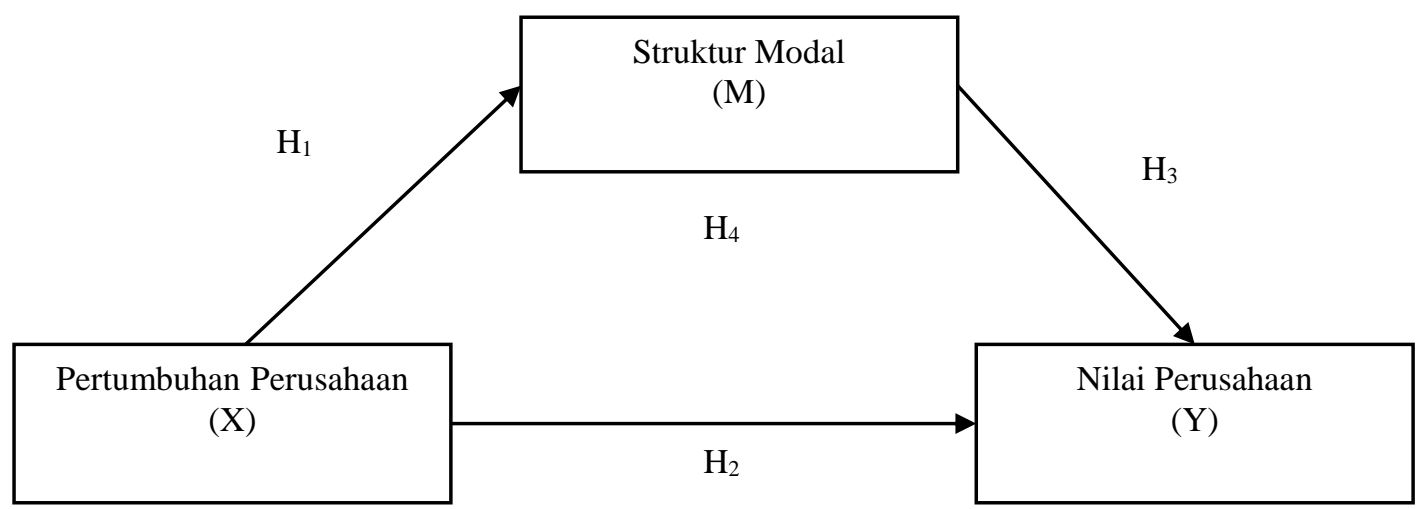

\section{Gambar 2. Kerangka Konseptual}

Sumber : data sekunder diolah, 2017

\section{METODE PENELITIAN}

Penelitian ini menggunakan pendekatan kuantitatif dan berdasarkan tingkat eksplansi penelitian, berbentuk asosiatif dengan tipe kausalitas, dimana penelitian yang berbentuk asosiatif dengan tipe kausalitas adalah penelitian yang menjelaskan pengaruh variabel independen (eksogen) terhadap variabel dependen (endogen).

Ruang lingkup wilayah penelitian ini dilakukan pada perusahaan properti dan real estate di Bursa Efek Indonesia (BEI) periode 2013-2016 dan Indonesian Capital Market Directory (ICMD). Pemilihan lokasi di BEI dan IMCD karena informasi yang tersedia mengenai mengenai data-data keuangan perusahaan dipublikasikan secara lengkap dan terinci. 
Obyek penelitian merupakan objek ataupun kegiatan yang memiliki kriteria yang telah ditetapkan oleh peneliti untuk dipelajari dan ditarik kesimpulannya (Sugiyono, 2013:38). Objek pada penelitian ini adalah nilai perusahaan.

Nilai perusahaan adalah nilai yang mencerminkan kinerja dari sebuah perusahaan, jika nilai perusahaan rendah maka kinerja dari perusahaan tersebut juga rendah dan begitu juga sebaliknya. PBV adalah perbandingan harga saham dengan nilai buku per lembar saham dengan satuan persen (Wiagustini, 2014:89).

$\mathrm{PBV}=\frac{\text { Harga perlembarsaham }}{\text { Nilai buku perlembar saham }} x 100 \%$

Struktur modal adalah perbandingan antara jumlah hutang jangka panjang dengan modal sendiri untuk membiayai aset jangka panjang perusahaan. Struktur modal diukur dengan debt to equity ratio (DER).

$\mathrm{DER}=\frac{\text { Total Utang }}{\text { Total Ekuitas }} \times 100 \%$

Pertumbuhan perusahaan adalah perubahan tahunan dari total aktiva dan dimana perusahaan mampu untuk meningkatkan atau memperluas ukuran perusahaan. Pertumbuhan dihitung menggunakan perubahan total asset perusahaan sebagai berikut (Kusumajaya, 2011).

Pertumbuhan $=\frac{\text { Total aset } \mathrm{t}-\text { Total aset } \mathrm{t}-1}{\text { Total aset } \mathrm{t}-1} \times 100 \%$

Populasi dalam penelitian ini adalah seluruh perusahaan properti dan real estate di Bursa Efek Indonesia periode tahun 2013-2016. Dengan populasi sebanyak 47 perusahaan diperoleh sampel sebanyak 32 perusahaan, dengan empat tahun pengamatan sehingga diperoleh jumlah pengamatan sebesar 128 perusahaan. Pengumpulan data dalam penelitian ini menggunakan metode 
observasi non partisipan. Jenis data dalam penelitian ini adalah data kuantitatif dimana berupa laporan keuangan perusahaan properti dan real estate di BEI selama periode 2013-2016. Data penelitian ini diperoleh dari sumber data sekunder. Data tersebut diakses dari situs resmi Bursa Efek Indonesia (BEI) yaitu www.idx.co.id dan Indonesian Capital Market Directory.

Analisis dalam penelitian ini diolah menggunakan program SPSS. Teknik analisis yang digunakan adalah analisis jalur (path analysis) dan uji sobel. Menurut solimun (2002) dalam Maharani (2012:118), ada enam langkah untuk menggunakan analisis jalur. Langkah-langkah dalam menggunakan analisis jalur ada enam yaitu langkah pertama adalah merancang model berdasarkan konsep dan teori. Dalam penelitian ini terdiri dari variabel pertumbuhan perusahaan (X) berpengaruh terhadap struktur modal $(\mathrm{M})$, variabel pertumbuhan perusahaan $(\mathrm{X})$ berpengaruh terhadap variabel nilai perusahaan (Y), dan variabel struktur modal (M) berpengaruh terhadap nilai perusahaan (Y). Langkah kedua adalah meregresikan setiap persamaan struktural antara variabel eksogen (bebas) dan endogen (terikat) untuk mengetahui hubungan antar variabel tersebut.

Langkah ketiga adalah menghitung koefisien jalur secara simultan. Hasil uji koefisien antar variabel secara keseluruhan ditunjukan pada tabel ANOVA. Jika angka signifkansi penelitian yang ditunjukan pada tabel ANOVA lebih dari atau sama dengan angka signifikansi yang telah ditentukan yaitu sebesar 0,05 maka korelasi antar variabel tersebut tidak signifikan secara keseluruhan. Jika angka signifkansi penelitian kurang dari atau sama dengan angkan signifikansi yang 
Kadek Ayu Citra Pradnya Paramita Parta, Peran Struktur Modal Dalam...

telah ditentukan sebesar 0,05 maka variabel tersebut signifikan secara keseluruhan.

Langkah keempat adalah menghitung korelasi antar variabel secara parsial. Hasil uji koefisien antar variabel secara keseluruhan ditunjukan pada tabel Coefficients. Jika angka signifikansi penelitian pada tabel Coefficient lebih dari satu atau sama dengan angka signifikansi yang telah ditentukan sebelumnya sebesar 0,05 maka variabel tersebut tidak signifikan secara individu. Sebaliknya, jika angka signifkansi penelitian pada tabel Coefficients kurang dari atau sama dengan angka signifkansi 0,05 maka variabel eksogen signifikan secara parsial dengan variabel endogennya. Langkah kelima adalah menetapkan besarnya pengaruh langsung, pengaruh tidak langsung dan pengaruh total serta uji validitas. Dan langkah keenam dan merupakan langkah terakhir dalam analisa jalur adalah menginterpretasikan hasil analisis yang telah diperoleh.

Uji sobel digunakan untuk menguji signifikansi Struktur Modal sebagai variabel mediasi hubungan Pertumbuhan Perusahaan terhadap Nilai Perusahaan maka digunakan uji Sobel (Ghozali, 2013:255), dengan rumus sebagai berikut:

$$
Z=\frac{a b}{\sqrt{b^{2} s_{a}^{2}+a^{2} s_{b}^{2}+s_{a}^{2} s_{b}^{2}}}
$$

Keterangan:

$Z$ = nilai kalkulasi sobel.

a $=$ koefisien regresi dari variabel independen terhadap variabel intervening

$\mathrm{s}_{\mathrm{a}}=$ varian dari $\mathrm{a}$.

$\mathrm{b}=$ koefisien regresi dari variabel intervening terhadap variabel dependen. 
$\mathrm{s}_{\mathrm{b}}=$ varian dari $\mathrm{b}$.

Sebuah variabel intervening dapat dikatakan mampu secara signifikan memediasi hubungan antara variabel independen dengan variabel dependen apabila nilai kalkulasi Z lebih besar dari 1,96 (dengan tingkat kepercayaan 95 persen).

\section{HASIL DAN PEMBAHASAN}

Data dalam analisis deskripsi pada penelitian ini diperoleh dari laporan keuangan tahunan perusahaan yang diakses pada www.idx.co.id yang dimuat dalam Indonesian Capital Market Directory (ICMD). Adapun hasil analisis deskripsi dalam penelitian ini adalah sebagai berikut.

Tabel 1.

Analisis Deskriptif Statistik

Descriptive Statistics

\begin{tabular}{lrrrrr}
\hline & N & minimum & maximum & mean & std. deviasi \\
\hline PBV & 128 & .120 & 4570 & 1.35492 & .813882 \\
GROWTH & 128 & -.164 & 1101 & .13502 & .171884 \\
DER & 128 & .070 & 2240 & .74953 & .482089 \\
Valid N (listwise) & 128 & & & & \\
& & & & & \\
\hline
\end{tabular}

Sumber: data sekunder diolah, 2017

Tabel 1 menunjukkan bahwa jumlah data yang digunakan dalam penelitian ini berjumlah 128, yang didapat dari jumlah sampel yang digunakan yaitu 32 perusahaan dikalikan dengan periode penelitian yaitu 4 tahun.

Berdasarkan perhitungan selama periode pengamatan yaitu 2013-2016, menunjukkan nilai perusahaan (PBV) terendah sebesar 0,120 yaitu pada 
Kadek Ayu Citra Pradnya Paramita Parta, Peran Struktur Modal Dalam...

perusahaan PT. Rista Bintang Mahkota Sejati (RBMS) tahun 2015 dan yang tertinggi adalah 4,570 yaitu pada perusahaan PT. Pakuwon Jati Tbk. (PWON) tahun 2014. Rata - rata perubahan nilai perusahaan adalah positif yaitu pada angka 1,35492 persen. Hal tersebut menunjukkan selama periode 2013-2016 terjadinya peningkatan nilai perusahaan (PBV) setiap tahunnya, dengan standar deviasi yang lebih rendah dibandingkan rata-rata PBV yaitu sebesar 0,813882 persen.

Leverage (DER) terendah dengan angka 0,070 persen pada perusahaan PT. Greenwood Sejahtera Tbk. (GWSA) dan PT. Rista Bintang Mahkota Sejati (RBMS) tahun 2016 untuk data DER tertinggi yaitu 2.240 pada perusahaan PT. Goa Makassar Tourism Development Tbk. (GMTD). Rata-rata leverage adalah positif yaitu dengan angka 0,74953 persen. Hal tersebut menunjukkan selama periode 2013-2016 terjadi peningkatan rata-rata leverage setiap tahunnya. Standar deviasi leverage adalah sebesar 0,482089 persen yang lebih rendah daripada rata rata leverage.

Data pertumbuhan perusahaan (Growth) terendah yakni pada angka $-0,164$ persen pada perusahaan PT. Goa Makassar Tourism Development Tbk. (GMTD) dan yang tertinggi sebesar 1.101 persen pada perusahaan PT. Modernland Realty Tbk. (MDLN). Rata-rata perubahan growth adalah positif pada angka 0,13502 persen. Standar deviasi growth adalah 0,171884 persen yang lebih render daripada rata - rata growth.

Untuk menguji apakah model regresi telah valid dan tidak melanggar asumsi metode derajat terkecil maka dilakukanlah uji asumsi klasik. Uji asumsi 
klasik terdiri dari empat pengujian yaitu uji normalitas, uji multikolinearitas, uji heterokdastisitas dan uji autokorelasi.

Dalam model regresi uji normalitas dilakukan untuk mengetahui apakah variabel pengganggu berdistribusi normal. Uji t dan $\mathrm{F}$ mengasumsikan bahwa nilai residual mengikuti distribusi normal (Ghozali, 2013:160). Uji normalitas pada penelitian ini dilakukan menggunakan uji Kolmogorov Smirnov. Apabila nilai koefisien pada Asymp. Sig. (2-tailed) lebih besar dari tingkat signifikansi yang digunakan $(0,05)$ maka model data yang digunakan berdistribusi normal. Berikut hasil pengujian normalitas.

Tabel 2

Hasil Uji Normalitas

Substruktur I One-Sample Kolmogorov-Smirnov Test

\begin{tabular}{|c|c|c|}
\hline \multicolumn{3}{|c|}{ unstandardized residual } \\
\hline $\mathrm{N}$ & & 128 \\
\hline \multirow[t]{2}{*}{ normal parameters $\mathrm{a,b}$} & mean & .0000000 \\
\hline & std. deviation & .45903080 \\
\hline most extreme & absolute & .115 \\
\hline \multirow[t]{2}{*}{ differences } & positive & .115 \\
\hline & negative & -.071 \\
\hline kolmogorov-smirnov & & 1,301 \\
\hline asymp. sig. (2-tailed) & & .068 \\
\hline
\end{tabular}

a. test distribution in normal

b. calculate from data

Sumber: data sekunder diolah, 2017

Berdasarkan tabel terssebut terlihat bahwa nilai koefisien asymp. sig. (2tailed) diperoleh dengan angka 0,068 dengan tingkat signifikansi yang digunakan pada penelitian ini sebesar 0,05. Pada penelitian ini nilai asymp. sig (2-tailed) lebih besar daripada tingkat signifikansi $(0,068>0,05)$ maka dapat disimpulkan bahwa data yang digunakan berdistribusi normal. 
Tabel 3.

Hasil Uji Normalitas

Substruktur II

One-Sample Kolmogorov-Smirnov Test

\begin{tabular}{llr}
\hline & & unstandardized residual \\
\hline $\mathrm{N}$ & & 128 \\
normal parameters ${ }^{\mathrm{a}, \mathrm{b}}$ & mean & .0000000 \\
& std. deviation & .72180662 \\
most extreme & absolute & .117 \\
differences & positive & .117 \\
& negative & -.070 \\
kolmogorov-smirnov Z & & 1,323 \\
asymp. sig. (2-tailed) & & .060 \\
\hline
\end{tabular}

a. test distribution in normal

b. calculate from data

Sumber : data sekunder diolah, 2017

Berdasarkan tabel tersebut menyatakan bahwa koefisien asymp. sig (2tailed) yang diperoleh adalah sebesar 0,060 dengan tingkat signifikansi yang digunakan sebesar 0,05. Nilai Asymp. Sig (2-tailed) sebesar 0,060 lebih besar daripada tingkat signifikansi $(0,060>0,05)$ berarti bahwa data yang digunakan adalah berdistribusi normal.

Untuk mengetahui ada atau tidanya korelasi antar variabel bebas yang diteliti dalam sebuah model regresi perlu dilakukan uji multikolinearitas. Apabila tidak terdapat korelasi antar variabel bebas maka model regresi tersebut dikatakan baik (Ghozali, 2013:105). Untuk melihat nilai multikolinearitas terlihat pada nilai tolerance dan variance inflation factor (VIF). Adanya multikolinearitas ditunjukkan dengan nilai tolerance yang lebih kecil atau sama dengan 0,10 dan nilai VIF lebih besar dari 10. Berikut hasil uji multikolinearitas pada substruktur I dan substruktur II. 
Tabel 4.

Hasil Uji Multikolinearitas

Substruktur I

Coefficients $^{\text {a }}$

\begin{tabular}{lcc} 
& \multicolumn{2}{c}{ collinearity statistics } \\
\multicolumn{1}{c}{ model } & tolerance & VIF \\
\hline 1 (constant) & & \\
growth & 1.000 & 1.000 \\
\hline
\end{tabular}

a. Dependent Variable: DER

Sumber : data sekunder diolah, 2017

Berdasarkan tabel tersebut terlihat bahwa variabel growth memiliki nilai tolerance dan VIF masing-masing lebih dari 0,1 dan nilai VIF kurang dari 10 maka dapat disimpulkan bahwa tidak terjadi gejala multikolinearitas.

Tabel 5.

Hasil Uji Multikolinearitas

Substruktur II

Coefficients ${ }^{\mathbf{a}}$

\begin{tabular}{lcc} 
& \multicolumn{2}{c}{ collinearity statistics } \\
\multicolumn{1}{c}{ model } & tolerance & VIF \\
\hline 1 (constant) & & \\
Growth & .907 & 1.103 \\
DER & .907 & 1.103 \\
\hline
\end{tabular}

Sumber : data sekunder diolah, 2017

Berdasarkan tabel tersebut terlihat bahwa variabel growth dan DER memiliki nilai tolerance dan VIF masing-masing lebih dari 0,1 dan nilai VIF kurang dari 10 maka dapat disimpulkan bahwa tidak terjadi gejala multikolinearitas. 
Uji glejser digunakan untuk melakukan uji heterokedastisitas, tidak adanya heterokedastisitas dalam model regresi diperoleh apabila nilai probabilitas signifikansi lebih tinggi dari tingkat signifikansi yang digunakan $(0,05)$.

Tabel 6.

Hasil Uji Heterokedastisitas

Substruktur I

Coefficients $^{\mathbf{a}}$

\begin{tabular}{|c|c|c|c|c|c|c|}
\hline \multirow[b]{2}{*}{ Model } & \multirow[b]{2}{*}{$\mathrm{B}$} & \multicolumn{2}{|c|}{$\begin{array}{l}\text { Unstandardized } \\
\text { Coefficients }\end{array}$} & \multirow{2}{*}{$\begin{array}{c}\text { Standardized } \\
\text { Coefficients } \\
\text { Beta } \\
\end{array}$} & \multirow[b]{2}{*}{$\mathrm{t}$} & \multirow[b]{2}{*}{ Sig. } \\
\hline & & & Std. Error & & & \\
\hline 1(Constant) & & .326 & .033 & & 9.825 & .000 \\
\hline Growth & & .183 & .152 & .107 & 1.207 & .230 \\
\hline
\end{tabular}

a. Dependent Variable: Absres 1

Sumber : data sekunder diolah, 2017

Berdasarkan tabel tersebut diketahui bahwa nilai signifikansi growth yaitu pada angka 0,230 yang lebih besar daripada tingkat signifikansi 0,05 , maka kesimpulannya adalah tidak terjadi heterokedastisitas pada model regresi I.

Tabel 7.

Hasil Uji Heterokedastisitas

Substruktur II

Coefficients $^{\mathbf{a}}$

\begin{tabular}{|c|c|c|c|c|c|}
\hline \multirow[b]{2}{*}{ Model } & \multicolumn{2}{|c|}{$\begin{array}{l}\text { Unstandardized } \\
\text { Coefficients }\end{array}$} & \multirow{2}{*}{$\begin{array}{c}\text { Standardized } \\
\text { Coefficients } \\
\text { Beta }\end{array}$} & \multirow[b]{2}{*}{$\mathrm{t}$} & \multirow[b]{2}{*}{ Sig. } \\
\hline & $\mathrm{B}$ & Std. Error & & & \\
\hline 1 (Constant) & .374 & .077 & & 4.880 & .000 \\
\hline Growth & .316 & .250 & .116 & 1.266 & .208 \\
\hline DER & .172 & .089 & .176 & 1.928 & .056 \\
\hline
\end{tabular}

a. Dependent Variable: Absres2

Sumber : data sekunder diolah, 2017 
Berdasarkan tabel tersebut diketahui bahwa nilai signifikansi growth dan DER yaitu masing - masing pada angka 0,230 dan 0,056 yang lebih besar daripada tingkat signifikansi 0,05 , maka kesimpulannya adalah tidak terjadi heterokedastisitas pada model regresi II.

Untuk mengetahui adanya korelasi antara kesalahan penganggu pada periode $\mathrm{t}$ dengan kesalahan penganggu pada periode $\mathrm{t}-1$ dalam model regresi linier dilakukan dengan uji autokorelasi (Ghozali, 2013:110). Hasil uji autokorelasi pada model I dan model II disajikan dalam tabel berikut.

Tabel 8.

Hasil Uji Autokorelasi

Substruktur I

Model Summary ${ }^{b}$

\begin{tabular}{|c|c|c|c|c|c|}
\hline Model & $\mathrm{R}$ & R Square & Adjusted R Square & $\begin{array}{l}\text { Std. Error Of The } \\
\text { Estimate }\end{array}$ & $\begin{array}{l}\text { Durbin - } \\
\text { Watson }\end{array}$ \\
\hline 1 & $.306^{\mathrm{a}}$ & .093 & .086 & .460849 & 2,033 \\
\hline
\end{tabular}

Sumber : data sekunder diolah, 2017

Nilai DW sebesar 2,033 dibandingkan dengan nilai tabel signifikansi 5\%, jumlah sampe 128 (n) dan jumlah variabel independen $1(\mathrm{~K}=2)$ maka diperoleh nilai $\mathrm{du}=1.7432$ dan nilai $\mathrm{dl}=1.6798$. Oleh karena nilai $\mathrm{du}<\mathrm{d}<(4-\mathrm{du})$ $(1.7432<2,033<2,2568)$, maka dapat disimpulkan tidak terdapat autokorelasi antar residual. 
Tabel 9.

Hasil Uji Autokorelasi

Substruktur II

Model Summary ${ }^{b}$

\begin{tabular}{|c|c|c|c|c|c|}
\hline Model & $\mathrm{R}$ & R Square & Adjusted R Square & $\begin{array}{l}\text { Std. Error Of The } \\
\text { Estimate }\end{array}$ & $\begin{array}{l}\text { Durbin - } \\
\text { Watson }\end{array}$ \\
\hline 1 & $.462^{\mathrm{a}}$ & .213 & .201 & .727558 & 1.910 \\
\hline
\end{tabular}

Nilai DW sebesar 1,910 dibandingkan dengan nilai tabel signifikansi 5\%, jumlah sampe 128 (n) dan jumlah variabel independen $2(\mathrm{~K}=2)$ maka diperoleh nilai $\mathrm{du}=1,7432$ dan $\mathrm{dl}=1,6798$. Oleh karena nilai $\mathrm{du}<\mathrm{d}<(4-\mathrm{du})$ $(1,7432<1910<2,2568)$, maka dapat disimpulkan tidak terdapat autokorelasi antar residual.

Pengujian pengaruh langsung dan tidak langsung antara pertumbuhan perusahaan (Growth) terhadap nilai perusahaan dengan struktur modal (DER) sebagai variabel mediasi dalam penelitian ini dilakukan dengan teknik analisis jalur (path). Penyelesaian model analisis jalur tersebut dibagi menjadi dua model yaitu model pertama pengaruh pertumbuhan perusahaan (Growth) terhadap nilai perusahaan. Model kedua yaitu pengaruh Pertumbuhan perusahaan dan Struktur modal terhadap Nilai perusahaan. Langkah-langkah analisis jalur dalam penelitian ini terdiri dari tiga langkah.

\section{Merumuskan persamaan strukturalnya}

$$
\begin{aligned}
& \mathbf{Y}_{\mathbf{1}}=\boldsymbol{\alpha}+\boldsymbol{\beta}_{\mathbf{1}} \mathbf{U P}+\mathbf{e}_{\mathbf{1}} \\
& \mathbf{Y}_{\mathbf{1}}=0,634+0,306 \mathrm{UP}+0,093 \\
& \mathbf{e} \mathbf{1}=\sqrt{1-R^{2}}=\sqrt{1-0,093}=0,952
\end{aligned}
$$




$$
\begin{aligned}
& \mathbf{Y}_{2}=\boldsymbol{\alpha}+\boldsymbol{\beta}_{1} \mathbf{U P}+\boldsymbol{\beta}_{\mathbf{2}} \mathbf{L}+\mathbf{e}_{2} \\
& \mathbf{Y}_{2}=0,818+0,298+0,213 \\
& \mathbf{e} 2=\sqrt{1-R^{2}}=\sqrt{1-0,213}=0,887
\end{aligned}
$$

\section{Diagram Jalur}

Bentuk diagram jalur pada gambar 1 menggambarkan secara singkat tentang hubungan antara setiap variabel yaitu struktur modal (M) sebagai variabel mediasi, pertumbuhan perusahaan (X) sebagai variabel eksogen dan nilai perusahaan (Y) sebagai variabel endogen.

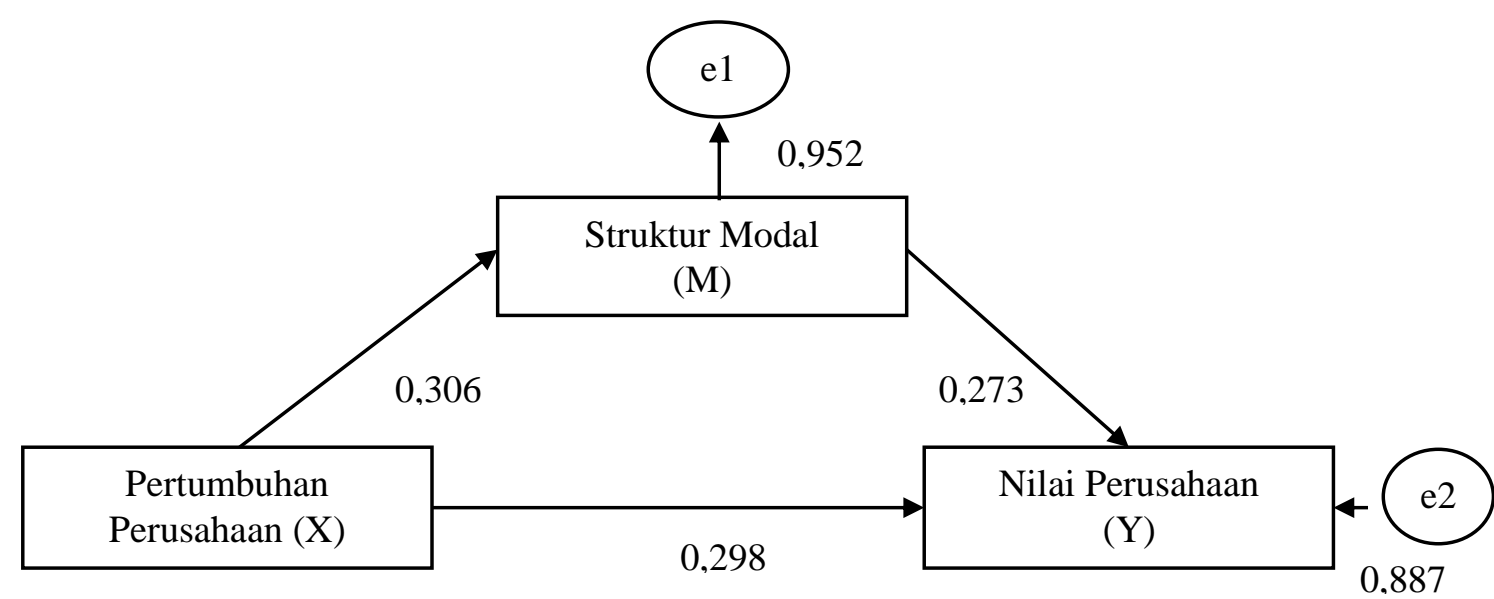

Gambar 3. Analisis Jalur Peran Struktur Modal dalam memedisi pengaruh Pertumbuhan Perusahaan terhadap Nilai Perusahaan.

Sumber : data sekunder diolah, 2017

\section{Koefisien Jalur Secara Simultan dan Parsial}

Bentuk analisis jalur diatas menjelaskan hubungan antara pertumbuhan perusahaan $(\mathrm{X})$ terhadap struktur modal $(\mathrm{M})$ memiliki standar koefisien 0,306 dengan nilai signifikan 0,000 . Pengaruh pertumbuhan perusahaan $(X)$ terhadap nilai perusahaan (Y) memiliki standar koefisien 0,298 dengan nilai signifikansi 
0,000. Selanjutnya pengaruh struktur modal $(\mathrm{X})$ terhadap nilai perusahaan $(\mathrm{Y})$ memiliki standar koefisien 0,273 dengan nilai signifikan 0,001 .

Tabel 10.

Koefisien Regresi

Substruktur I

ANOVA ${ }^{b}$

\begin{tabular}{llrccc}
\hline Model & $\begin{array}{l}\text { Sum of } \\
\text { Squares }\end{array}$ & Df & Mean Square & F & Sig. \\
\hline 1 Regression & 2.756 & 1 & 2.756 & 12.977 & $.000^{\mathrm{a}}$ \\
Residual & 26.760 & 126 & .212 & & \\
Total & 29.516 & 127 & & & \\
\hline
\end{tabular}

a. Predictors: (Constant), Growth

b. Dependent Variable: DER

Sumber : data sekunder diolah, 2017

Hasil uji $\mathrm{F}$ yang diperoleh menunjukkan nilai $\mathrm{F}$ sebesar 12,977 dengan signifikansi $0,000<0,05$ (tingkat signifikansi yang digunakan). Hal ini menunjukkan bahwa Growth berpengaruh simultan dan signifikan terhadap DER.

Tabel 11.

Koefisien Regresi

Substruktur II

Coefficients $^{\mathbf{a}}$

\begin{tabular}{lcc} 
& \multicolumn{2}{c}{ Collinearity Statistics } \\
\multicolumn{1}{c}{ Model } & Tolerance & VIF \\
\hline 1 (Constant) & & \\
Growth & 1.000 & 1.000 \\
\hline
\end{tabular}

a. Dependent Variable: DER

Sumber : data sekunder diolah, 2017

Berdasarkan tabel 12 diketahui bahwa nilai signifikansi sebesar $0,000<$ 0,05 maka Ho diterima, hasil ini menunjukkan adanya pengaruh yang signifikan antara Growth dan DER pada perusahaan Properti dan real estate di BEI. Nilai 
beta 0,306 menunjukkan arah yang positif. Nilai ini memiliki arti bahwa Growth berpengaruh positif terhadap DER Jika Growth pada Perusahaan Properti dan Real estate di BEI meningkat, maka PBV akan meningkat pula.

\section{Tabel 12 Koefisien Regresi}

Substruktur I

ANOVA ${ }^{b}$

\begin{tabular}{llcccc}
\hline Model & $\begin{array}{l}\text { Sum of } \\
\text { Squares }\end{array}$ & Df & Mean Square & F & Sig. \\
\hline 1 Regression & 17.958 & 2 & 8.979 & 16.692 & $.000^{\mathrm{a}}$ \\
\hline Residual & 66.168 & 125 & .529 & \\
\hline Total & 84.125 & 127 & & \\
\hline $\begin{array}{l}\text { a. } \\
\text { b. }\end{array}$ & Dredictors: (Constant), DER, GROWTH & & \\
\hline
\end{tabular}

Sumber : data sekunder diolah, 2017

Hasil uji $\mathrm{F}$ yang diperoleh menunjukkan nilai $\mathrm{F}$ sebesar 16,692 dengan signifikansi $0,000<0,05$ (tingkat signifikansi yang digunakan). Hal tersebut menunjukkan bahwa Growth dan DER berpengaruh secara simultan dan signifikan terhadap PBV.

Tabel 13.

Koefisien Regresi

Substruktur II

Coefficients $^{\mathbf{a}}$

\begin{tabular}{lcc} 
& \multicolumn{2}{c}{ Collinearity Statistics } \\
\multicolumn{1}{c}{ Model } & Tolerance & VIF \\
\hline 1 (Constant) & & \\
Growth & .907 & 1.103 \\
DER & .907 & 1.103 \\
\hline
\end{tabular}

a. Dependent Variable: PBV

Sumber : data sekunder diolah, 2017 
Kadek Ayu Citra Pradnya Paramita Parta, Peran Struktur Modal Dalam...

Berdasarkan tabel 14 diketahui bahwa nilai signifikansi sebesar 0,000< 0,05 maka Ho diterima, hasil ini menunjukkan adanya pengaruh yang signifikan antara Growth terhadap PBV pada perusahaan Properti dan Real estate di BEI. Nilai beta 1,412 menunjukkan arah yang positif, nilai ini memiliki arti bahwa Growth berpengaruh positif terhadap PBV. Jika Growth pada perusahaan Properti dan Real estate di BEI meningkat, maka PBV akan meningkat pula, dan begitu juga sebaliknya.

Berdasarkan tabel 14 diketahui bahwa nilai signifikansi sebesar 0,001 < 0,05 maka Ho diterima, hasil ini menunjukkan adanya pengaruh yang signifikan antara DER terhadap PBV pada perusahaan Properti dan Real estate di BEI. Nilai beta 0,462 menunjukkan arah yang positif, nilai ini memiliki arti bahwa DER berpengaruh positif terhadap PBV. Jika DER pada perusahaan Properti dan Real estate di BEI meningkat maka PBV akan meningkat pula, dan begitu juga sebaliknya.

Berdasarkan hasil analisis jalur (path), maka dapat dihitung pengaruh langsung, pengaruh tidak langsung dan pengaruh total dari model yang telah dibuat. Perhitungan pengaruh langsung, tidak langsung dan total tersebut dapat dilihat pada tabel berikut: 
Tabel 14.

Pengaruh Langsung, Pengaruh Tidak Langsung dan Pengaruh Total

\begin{tabular}{ccc}
\hline & Koefisien & Signifikansi \\
\hline Pengaruh Langsung: & & \\
\hline Growth $\rightarrow$ DER & 0,306 & 0,000 \\
\hline Growth $\rightarrow$ PBV & 0,298 & 0,000 \\
\hline DER $\rightarrow$ PBV & $\mathbf{0 , 2 7 3}$ & $\mathbf{0 , 0 0 1}$ \\
\hline
\end{tabular}

Pengaruh tidak langsung:

Growth $\rightarrow$ DER $\rightarrow$ PBV $\quad(0,306) \times(0,273)=0,083$

Pengaruh total:
Growth $\rightarrow$ PBV
$($ Growth $\rightarrow$ DER $\rightarrow$ PBV)

Sumber : data sekunder diolah, 2017

\section{Pemeriksaan Validasi Model}

$$
\begin{aligned}
& \mathrm{R}^{2} \mathrm{~m}=1-\left(\mathrm{e}_{1}\right)^{2}\left(\mathrm{e}_{2}\right)^{2} \\
& =1-(0,952)^{2}(0,887)^{2} \\
& =1-(0,9063)(0,7867) \\
& =1-0,7129 \\
& =0,2871 \text {. }
\end{aligned}
$$

Variasi data yang dipengaruhi oleh model sebesar $28,71 \%$ artinya informasi yang terkandung dalam data sebesar $28,71 \%$ dapat dijelaskan oleh model, sedangkan sisanya sebesar 71,29\% dijelaskan oleh variabel lain diluar model.

\section{Uji Sobel}

$$
\begin{aligned}
& Z=\frac{a b}{\sqrt{a^{2} s_{b}^{2}+b^{2} s_{a}^{2}+s_{a}^{2} s_{b}^{2}}} \\
& Z=\frac{0,462 \times 0,857}{\sqrt{0,462^{2} 0,238^{2}+0,857^{2} 0,141^{2}+0,141^{2} 0,238^{2}}}
\end{aligned}
$$




$$
\begin{aligned}
& Z=\frac{0,3959}{\sqrt{0,0120+0,0145+0,0011}} \\
& Z=2,4333 \ldots \ldots \ldots \ldots \ldots \ldots \ldots \ldots \ldots \ldots \ldots \ldots \ldots
\end{aligned}
$$

Nilai $Z>1,96=2,4333>1,96$ maka dapat dikatakan variabel intervening dinilai secara signifikan memediasi hubungan antara variabel independen dengan variabel dependen.

\section{SIMPULAN DAN SARAN}

Berdasarkan analisis dan pembahasan hasil peneltian yang telah diuraikan sebelumnya, dapat disimpulkan bahwa pertumbuhan perusahaan berpengaruh positif signifikan terhadap struktur modal, pertumbuhan perusahaan berpengaruh positif dan signifikan terhadap nilai perusahaan, sruktur modal berpengaruh positif dan signifikan terhadap nilai perusahaan dan struktur modal mampu memediasi pengaruh pertumbuhan perusahaan terhadap nilai perusahaan.

Disarankan bagi pihak perusahaan agar lebih memperhatikan lagi pertumbuhan asset, struktur modal dan nilai perusahaan yang dimiliki. Sehingga dalam menentukan keputusan untuk berinvestasi, calon investor akan tertarik untuk membeli saham milik perusahaan serta untuk mengetahui lebih jelas mengenai keadaan perusahaan.

\section{REFERENSI}

Chen Shun Yu and Li Jun Chen. 2011. Capital structure determinants: An empirical study in Taiwan. African Journal of Business Management, 5 (27). ISSN: 1993-8233. Pp.01-21. 
Dewi Ayu Sri Mahatma, Wirajaya Ary. 2013. Pengaruh Struktur Modal, Proditabilitas dan Ukuran Perusahaan Pada Nilai Perusahaan. E-Jurnal Akuntansi Universitas Udayana, 24 (2), ISSN: 2302-8556. Pp.358-372.

Dewi Putu Yunita Saputri, Gede Adi Yuniarta, Ananta Wikrama Tungga Atmadja. 2014. Pengaruh Struktur Modal, Pertumbuhan dan Profitabilitas terhadap Nilai Perusahaan pada Perusahaan LQ 45 di Bursa Efek Indonesia Periode 2008-2012. e-Journal S1 Ak Universitas Pendidikan Ganesha, 2 (10). Pp.01-10.

Fauziah Fenty dan Rusdiah Iskandar. 2015. Determinants of Capital Structure in Indonesian Banking Sector. International Journal of Business and Management Invention, 4 (12), ISSN 2319-8028. Pp.36-44.

Ghozali, Imam, 2013. Aplikasi Analisis Multivariate Dengan Program IBMM SPSS 21 Update PLS Regresi. Edisi ketujuh. Semarang : Badan Penerbit Universitas Diponegoro.

Hamidy Rahman Rusdi, I Gusti Bagus Wiksuana, Luh Gede Sri Artini. 2015. Pengaruh Struktur Modal Terhadap Nilai Perusahaan Dengan Profitabilitas Sebagai Variabel Intervening Pada Perusahaan Properti dan Real Estate di Bursa Efek Indonesia. E-Jurnal Ekonomi dan Bisnis Universitas Udayana, 4 (10). Pp.665-682.

Husnan, Suad. 2014. Manajemen Keuangan Teori dan Penerapan (Keputusan Jangka Panjang). Edisi Keempat. Yogyakarta: BPFE.

Holong J. Manullang. (2011). Analisis Faktor-Faktor Yang Mempengaruhi Struktur Modal Perusahaan LQ 45 Periode 2005-2010. Skripsi.Universitas Diponegoro.

Jogiyanto, 2013, Teori Portofolio dan Analisis Investasi. Edisi ke-8, Yogyakarta: BPFE.

Kariuki Samuel Nduati dan Kamau Charles Guandaru. 2014. Determinants of Corporate Capital Structure among Private Manufacturing Firms in Kenya: A Survey of Food and Beverage Manufacturing Firms. International Journal of Academic Research in Accounting, Finance and Management Sciences, 4 (3). ISSN 225-8329. Pp.49-62.

Kuncoro, Dwi Setiyo, R. Rustam Hidayat, Dwiatmanto. 2014. Penetapan Struktur Modal Optimum Dalam Hubungannya Dengan Biaya Modal dan Nilai Perusahaan. Jurnal Administrasi Bisnis, 16 (01). Pp.01-10.

Kusumajaya, Dewa Kadek Oka. 2011. Pengaruh Struktur Modal Dan Pertumbuhan Perusahaan Terhadap Profitabilitas dan Nilai Perusahaan Pada Perusahaan Manufaktur Di Bursa Efek Indonesia. Tesis S2, Universitas Udayana. 
Maharani, Satia Nur. 2012. Kandungan Informasi Lebih dan Arus Kas Terhadap Reaksi Perubahan Return Saham. Jurnal Keuangan dan Perbankan, 16 (01). Pp.86-98.

Martono dan A.D. Harjito. 2013. Manajemen Keuangan, Cetakan Ketiga. Penerbit EKONISIA. Yogyakarta.

Martono dan A. Harjito. 2014. Manajemen Keuangan. Edisi kedua. EKONISIA. Yogyakarta.

Meidiawati Karina. 2016. Pengaruh Size, Growth, Profitabilitas, Struktur Modal, Kebijakan Dividen terhadap Nilai Perusahaan. Jurnal Ilmu dan Riset Akuntansi, 5 (2), ISSN : 2460-0585. Pp.01-16.

Myers, S.C. 1984. The capital structure puzzle. The Journal of Finance, 39 (3). Pp.575-592.

Pakpahan, R. 2010. Pengaruh Faktor-faktor Fundamental Perusahaan dan Kebijakan Dividen terhadap Nilai Perusahaan (Studi Kasus pada Perusahaan Manufaktur di BEI tahun 2003-2007. Jurnal Ekonomi, Keuangan, Perbankan dan Akuntansi, 2 (2). Pp.221-227.

Rehman Obaid Ur. 2016. Impact of Capital Structure and Dividend Policy on Firm Value. Journal of Poverty, Investment and Development. 21. ISSN 2422-846X. Pp.40-57

Riyanto, B. 2015. Dasar-Dasar Pembelanjaan Perusahaan. Edisi Keempat. Cetakan Ketujuh. Yogyakarta: BPFE.

Rodoni, Ahmad dan Herni Ali. 2014. Manajemen Keuangan Modern. Jakarta: Mitra Wacana Media.

Saraswathi, Ida Ayu Anggawulan, I Gusti Bagus Wiksuana, Henny Rahyuda. 2016. Pengaruh Risiko Bisnis, Pertumbuhan Perusahaan dan Struktur Modal Terhadap Profitabilitas Serta Nilai Perusahaan Manufaktur. E-Jurnal Ekonomi dan Bisnis Universitas Udayana. 5 (6). Pp.1729-1756.

Sari Pt Indah Purnama, Abundanti Nyoman. 2014. Pengaruh Pertumbuhan Perusahaan dan Leverage Terhadap Profitabilitas dan Nilai Perusahaan. EJurnal Manajemen Universitas Udayana, 3 (5). ISSN 2302-8912. Pp.14271441.

Shah Attaullah dan Khan Safiullah. 2007. Determinants of Capital Structure: Evidence from Pakistani Panel Data. International Review of Business Research Papers, 3 (4). Pp.265-282.

Seikh Nadeem Ahmed dan Zongjung Wang. 2011. Determinants of Capital Structure: An Imperical Study of Firms in Manufacturing Industry of Pakistan. Managerial Finance, 37 (2). Pp.117-133. 
Sualehkhattak Muhammad, Hussain CH Mazzer. 2017. Do Growth Opportunities Influence the Relationship of Capital Structure, Dividend Policy and Ownership Structure with Firm Value: Empirical Evidence of KSE?. Journal of Accounting and Marketing, 6 (1). Pp.01-11.

Sugiyono. 2013. Metodologi Penelitian Bisnis (Pendekatan Kuantitatif, Kualitatif, dan $R \& D)$. CV. Bandung : Alfabeta.

Sujoko dan Ugy Soebiantoro. 2007. Pengaruh Struktur Kepemilikan Saham, Leverage, Faktor Intern dan Faktor Ekstern terhadap Nilai Perusahaan. Jurnal Manajemen dan Kewirausahaan, 9 (1). Pp.41-48.

Sutrisno. 2016. Capital Structure Determinants and Their Impact on Firm Value: Evidence From Indonesia. Economics World, 4 (4). Pp.179-186.

Velnampy, T and J. Aloy, Niresh. 2012. The Relationship between Capital Structure and Profitability. Global Journal of Management and Business Research, 12 (13). Pp.67-74.

Wahab Siti Nur Aqilah Ab, Ramli Nur Ainna. 2014. The Determinants of Capital Structure: An Empirical Investigation of Malaysian Listed Government Linked Companies. International Journal of Economics and Financial Issues, 4 (4), ISSN: 2146-4138. Pp.930-945.

Wiagustini, Ni Luh Putu, 2014, Dasar-Dasar Manajemen Keuangan, Denpasar : Udayana University Press.

Widayanti Luh Putu, Nyoman Triaryati, Nyoman Abundanti. 2016. Pengaruh Profitabilitas, Tingkat Pertumbuhan Perusahaan, Likuiditas dan Pajak Terhadap Struktur Modal Pada Sektor Pariwisata. E-Jurnal Manajemen Unud, 5 (6), 3761-3793. ISSN : 2302-8912. Pp.3761-3793.

Windayu Cinde Ririh. 2016. Factors Affecting the Capital Structure in Textile and Garment Listed in Indonesia Stock Exchange. IOSR Journal of Business and Management, 18 (10), ISSN: 2319-7668. Pp.83-88.

Wijaya I Putu Andre Sucita, I Made Karya Utama. 2014. Pengaruh Profitabilitas, Struktur Aset ,dan Pertumbuhan Penjualan Terhadap Struktur Modal Serta Harga Saham. E-Jurnal Akuntansi Universitas Udayana, 6 (3), 514-530. ISSN: 2302-8556. Pp.514-530.

www.idx.co.id. 